\title{
Low mammal and hornbill abundance in the forests of Barito Ulu, Central Kalimantan, Indonesia
}

\author{
Kim R. McConkey and David J. Chivers
}

\begin{abstract}
Faunal surveys in Kalimantan have been biased towards primates in protected forests close to the coast. Relatively little has been documented on other animal species, particularly in the vast interior forests. The results of a 1996-97 census of nine large mammal and eight hornbill species in tropical lowland forest in Barito Ulu, Central Kalimantan are reported here. Pigs Sus barbatus had the highest biomass, but this was due to large numbers migrating through the study area over 4 months and the resident population is probably low. Langurs Presbytis rubicunda and hybrid gibbons Hylobates mulleri $\mathrm{x}$ agilis had the highest biomass of all resident species. Orang-utans Pongo pygmaeus were absent from the area during the study period and pig-tailed macaques Macaca nemestrina were rarely seen. The resident hornbill species (Anthracoceros malayanus, Anorrhinus galeritus, Buceros vigil and B. rhinoceros) had high densities compared to that reported from lowland areas, but overall hornbill density was low due to the absence
\end{abstract}

of the nomadic Aceros corrugatus and A. undulatus, except during peak fruit abundance. Sun bears Helarctos malayanus, long-tailed macaques $M$. fascicularis, muntjacs Muntiacus spp. and mouse deer Tragulus spp. were at low densities. Density of two large squirrel species, Ratufa affinis and Sundasciurus hippiurus, was lower than has been reported in Sarawak, but the density of Prevost's squirrel Callosciurus prevostii was higher. We discuss hunting pressure, isolation, low abundance of large fruit trees, poor soils, and specific habitat preferences as possible explanations for the low mammal and hornbill density at Barito Ulu.

Keywords Barito Ulu, Borneo, census, hornbills, Kalimantan, primates, squirrels, sun bears, ungulates.

This paper contains supplementary material that can only be found online at http://journals.cambridge.org

\section{Introduction}

More than $50 \%$ of Kalimantan's pristine forests have already been lost and the remainder continue to be threatened by human activities (Rijksen \& Meijaard, 1999). Despite serious conservation concern, faunal distribution throughout Kalimantan and the rest of Borneo is poorly documented. Surveys that have been conducted have tended to focus on orang-utans Pongo pygmaeus and, to a lesser extent, other primates in protected areas close to the coast (Rodman, 1978; Leighton, 1982; Payne \& Davies, 1982; Leighton \& Leighton, 1983; Galdikas, 1988; Nijman, 2001; Russon et al., 2001; Felton et al., 2003) and these may not be representative of animal abundance in other parts of Borneo. Coastal regions in Borneo tend to have a mixture of lowland dipterocarp, peat and swamp forest, compared to a mixture of lowland dipterocarp,

Kim R. McConkey ${ }^{1}$ (Corresponding author) and David J. Chivers Wildlife Research Group, Department of Anatomy, Cambridge University, Cambridge, CB2 3DY, UK.

1Present address: A. V. Ramarao Research Foundation, 7-102/54 Sai Enclave, Habshiguda, Hyderabad 500007, India. E-mail kimm@sancharnet.in

Received 1 October 2003. Revision requested 19 January 2004. Accepted 4 May 2004. hill and heath forest in the island's vast interior (MacKinnon et al., 1996). Soil richness also varies and this is likely to influence fruit productivity and the minerals available to the various animals (Payne, 1995). Moreover, while human populations are higher near the coast, traditional communities tend to be focused in the interior region and it is these communities that hunt wild meat most frequently (Bennett et al., 2000). Given that parts of Kalimantan continue to be rapidly deforested, it is crucial that our understanding of faunal distribution and abundance is improved.

Barito Ulu in Central Kalimantan supports a rich diversity of animals (Bodmer et al., 1991b), reflecting the area's rich geological history and its status as a meeting zone of expanding Sumatran and Bornean fauna during the Pleistocene (Chivers, 1992). Bodmer et al. (1991a) surveyed the primates and ungulates in the area over two months in 1989 and suggested the low densities they found were due to poor fruit supplies in the area. Due to the short duration of their survey, however, they were not able to record fluctuations in animal numbers that may occur (i.e. whether all species are supported year round) and they did not survey many of the large animals present. The aims in this paper are to determine the density of large diurnal mammals and hornbills at 


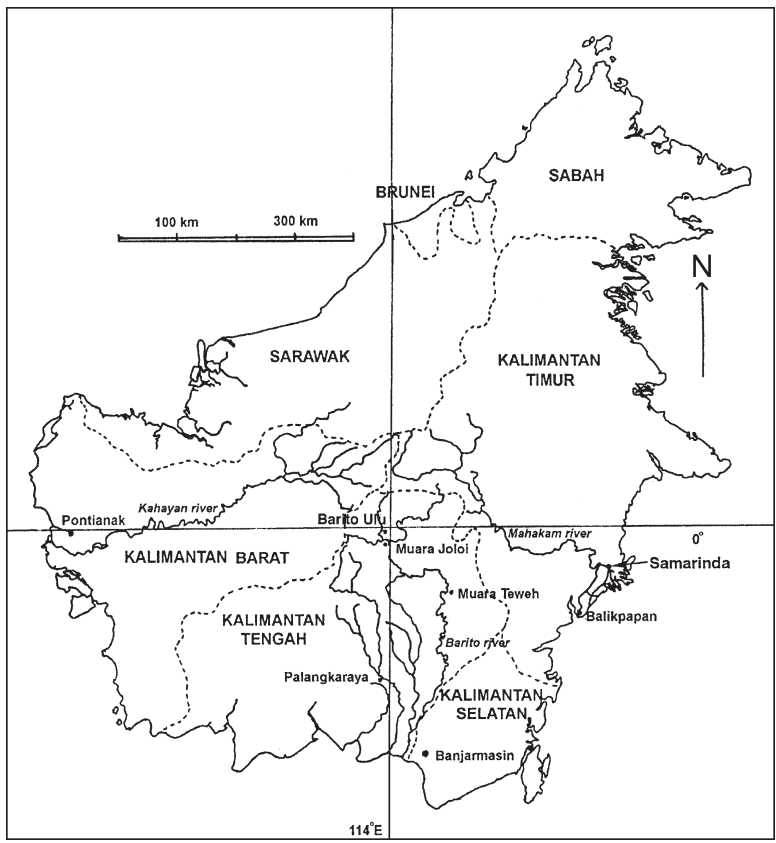

Fig. 1 Map of Borneo showing the regions of Kalimantan and the location of the study site.

Barito Ulu in Central Kalimantan and to describe how these numbers fluctuate during the year.

\section{Study area}

Field data were collected at the Barito Ulu Research Area, Central Kalimantan, Indonesia, from October 1996 to September 1997. The Research Area is in the watershed of the upper Barito River (Fig. 1). The area has a rugged, hilly to mountainous terrain, with altitudes of 100-350 m. The most extensive forest type is lowland dipterocarp, interspersed with smaller areas of heath forest and shifting cultivation fallows (dating from c. 1944 to $c .1980$ ) (Mirmanto, 1996; Proctor et al., 2001). Virtually all riverine forest has been cleared at some stage and these areas now support secondary forest of various ages (Mather, 1992). The present survey was conducted in lowland dipterocarp forest. This forest type is floristically diverse at Barito Ulu; $26 \%$ of all trees are Dipterocarpaceae, followed in importance by Euphorbiaceae (9\%), Anacardiaceae (5\%) and Sapotaceae (5\%) (Mirmanto, 1996).

The soils in the Research Area are residual and developed on sandstone, mudstone or alluvium. All soils, both in heath and lowland dipterocarp forest, are acidic and poor in nutrients, with low concentrations of nitrogen and phosphorus compared to other South-east Asian lowland forests (Mirmanto, 1996). The mean annual rainfall for 1990-1997 was 3,738 mm, but the latter months of the study period coincided with a severe drought, and the total rainfall in 1997 was 2,585 mm. Mean maximum and minimum temperatures are 34 and $22^{\circ} \mathrm{C}$, respectively. Dipterocarps began mass flowering in the last month of study, but fruit did not develop until after the study had ended.

The nearest village to the Research Area, Muara Joloi, is $20 \mathrm{~km}$ down-river. Approximately half the population (700 people in 1995) are Muslim and half are Dayak (Hall, 1995). The main activities in the area at the time of the study were subsistence agriculture, gold extraction from the rivers (almost completely confined to Muara Joloi), fishing and hunting. Logging began $10 \mathrm{~km}$ up-river near the end of the study period, but the immediate surrounding area had not been cut for some time. Several days journey up-river from our survey camp there is a system of caves from which edible birds nests were harvested. The most immediate influence of this on the Research Area was regular transport (1-2 speedboats per day) to a village above the Research Area, which was the base for trips to these caves. Edible birds nests were also extracted from a small cave 4-5 hours walk inland from the camp. Hunters were occasionally seen within the Research Area but sightings were not common. We saw evidence for hunting of pig, sambar, muntjac, mouse deer, pheasants and small songbirds in nearby areas.

\section{Methods}

Densities of large diurnal mammals and hornbills were estimated using the line transect method. The presence of animals other than large diurnal mammals and hornbills was noted, but their densities were not estimated. Species sighted other than along the transects were also noted. We established three trails, totalling $10 \mathrm{~km}$, within the Research Area. Six days each month were spent surveying animals along these trails; each trail was walked twice per month, changing the walking direction for the second survey, which was usually 3 days after the first. Surveying was carried out between 05.30 and 10.00, when the animals were most active. If it began to rain the census was halted until the rain ceased, or aborted completely if it continued to rain heavily. Trails were walked slowly, stopping every $20 \mathrm{~m}$ for $c$. 10 seconds to check the area ahead. When animals were sighted the species and group size were recorded. The perpendicular distance from trail to animal was estimated by eye and later corrected by applying the mean error between estimated and actual distances (determined by first estimating and then measuring distances to various objects in the forest).

Densities of individual species were calculated using four methods: (1) Actual density was known for three species, since all groups were regularly monitored in the study area: gibbons Hylobates mulleri x agilis, red langurs Presbytis rubicunda and bushy-crested hornbills 
Anorrhinus galeritus. (2) Using the perpendicular distance from the trail to sightings the software DISTANCE (Laake et al., 1994) was used for species with numerous sightings: giant Ratufa affinis and Prevost's squirrel Callosciurus prevostii, bearded pigs Sus barbatus, muntjacs Muntiacus spp. and the black Anthrococeros malayanus and rhinoceros hornbill Buceros rhinoceros. The halfnormal model of DISTANCE was used to estimate the effective strip width (ESW) using the cosine adjustment facility to ensure the best fit between data and model. (3) ESW was generated from DISTANCE for a particular animal group and the densities calculated for each species, using density $=$ no. sightings $/$ (width $\times$ transect length). For helmeted Buceros vigil, wrinkled Aceros corrugatus, wreathed Aceros undulates, white-crowned Aceros comatus and Oriental pied hornbills Anthracoceros albirostris we used the ESW for all hornbills combined, whereas for the horse-tailed squirrel Sundasciurus hippiurus we used the ESW for Prevost's squirrel, which is similar in body size and, hence, detectability is probably similar. (4) The maximum reliable width method (Kelker, 1945, in Eisenberg et al., 1981) to estimate ESW was used for species for which there were insufficient observations to use DISTANCE (macaques Macaca fascicularis and $M$. nemestrina, sun bears Helarctos malayanus and mouse deer Tragulus spp.). This involves examination of histograms of detection distance and subjectively determining at which distance most individuals can be reliably sighted.

Not all hornbill sightings could be identified to species level, and therefore family density was also determined. Muntjac (Muntiacus muntjac and M. atherodes) and mouse deer (Tragulus javanicus and T. napu) were identified to genus only, but all four species are known to occur in the area (Dutson et al., 1989). Biomass estimates were generated using body weights in Payne et al. (1985) and Kemp (1995). The proportion of males and females were considered in the calculation when body weights for both sexes were available. The weight of subadult individuals (mammals only) was taken as 0.75 the adult weight and juveniles as 0.5 .

To determine if the number of sightings of the commonly seen species varied during the year we tested the fit of the data to a rectangular distribution, which assumes equal numbers of sightings in all months, using the Kolmogorov-Smirnov test. To determine if the observed fluctuations in observations were associated with fruit availability, as all surveyed animals eat fruit to varying degrees, we calculated the Spearman-rank correlation of the number of individuals of each taxa seen each month with fruit (fig and non-fig) availability. If this test was also significant only the Spearman-rank values are shown in the results. One thousand trees were selected for the monitoring of fruit availability using the pointcentre-quarter method (Mueller-Dombois \& Ellenberg, 1974). The four closest trees (one per quadrant) with diameter at breast height $>10 \mathrm{~cm}$ were selected and marked every $20 \mathrm{~m}$ along $5 \mathrm{~km}$ of the census transects. All 118 fig trees and their lianas that could be observed from these trails were also marked, and monitored for fruit during 1 week each month by the same two observers. The density of trees with fruit was calculated for each month, using methods given in McConkey et al. (2003). All statistical analysis was carried out using STATISTICA version 4.1 (Statsoft, 1994).

\section{Results}

From October 1996 to September 1997 a total distance of $240 \mathrm{~km}$ was walked along the transects. Data from the last month of census were not used in the density analyses as smoke from fires burning throughout Borneo at the time made viewing animals difficult and may have affected the animals' behaviour. Twelve large diurnal mammal species, 13 nocturnal mammals and eight hornbill species were observed during the study period (Table 1, Appendix 1).

Bearded pigs Sus barbatus had the highest biomass in the area, but they were only seen over April-July when groups of up to 30 migrated through the study area (Fig. 2). Density was estimated only for the months of the migration, which coincided with the period of maximum non-fig fruit availability (Spearman rank, $\mathrm{r}=0.70$; $P=0.01$ ). Pigs were never seen in the area before the migration but we found tracks indicating the probable presence of a small resident population.

Of the resident animals, primates had the highest biomass, mostly red langurs Presbytis rubicunda and hybrid gibbons Hylobates mulleri $x$ agilis (Table 1). Long-tailed macaques Macaca fascicularis were present at a low density. A lone male pig-tailed macaque Macaca nemestrina was seen once along the transect and once at another time (not necessarily the same individual), and the species probably occupies a large home range or is nomadic. Primate densities in this study were similar to those calculated by Bodmer et al. (1991a) in 1989 (Table 2). Numbers of gibbon (Kolmogorov-Smirnov, $\mathrm{d}=0.39$, $\mathrm{P}>0.05)$, langur $(\mathrm{d}=0.38, \mathrm{P}>0.05)$ and long-tailed macaque groups $(\mathrm{d}=0.31, \mathrm{P}>0.05)$ seen each month did not vary throughout the year; pig-tailed macaque sightings were too few for the testing of any trend.

Muntjacs Muntiacus spp. occurred at a low density in the study area (Table 1) and we did not detect any change in sighting frequency over the year $(\mathrm{d}=0.36, \mathrm{P}>0.05)$. Mouse deer Tragulus spp. were also present but were seen mainly during the most productive non-fig fruit-bearing months $(\mathrm{r}=0.53, \mathrm{P}=0.10)$. Muntjac 
Table 1 Census of large mammals and hornbills at Barito Ulu, Central Kalimantan in 1996-97, with the total number of observations of animal groups (unless actual density was known), probability of observation (for species whose density was estimated using DISTANCE; see text for details), group size, density and total biomass; 95\% confidence intervals are shown for those values estimated using DISTANCE.

\begin{tabular}{|c|c|c|c|c|c|}
\hline Species & No. observations. & $\begin{array}{l}\text { Probability of } \\
\text { observation }(\%)^{1}\end{array}$ & Group size & Individuals per $\mathrm{km}^{2}$ & Biomass $\left(\mathrm{kg} \mathrm{km}^{-2}\right)$ \\
\hline Presbytis rubicunda & - & - & 4.3 & 8.4 & 43.7 \\
\hline Macaca fascicularis & 7 & - & 1.4 & 1.5 & 4.8 \\
\hline M. nemestrina & 1 & - & 1.0 & 0.2 & 1.6 \\
\hline Hylobates mulleri $\mathrm{x}$ agilis & - & - & 3.5 & 8.2 & 36.9 \\
\hline Ratufa affinis & 41 & $33.6 \pm 13.3^{* * *}$ & $1.1 \pm 0.1$ & $5.2 \pm 9.1$ & $6.1 \pm 3.3$ \\
\hline Callosciurus prevostii & 68 & $20.5 \pm 4.5^{* * *}$ & $1.1 \pm 0.1$ & $14.6 \pm 5.7$ & $5.5 \pm 1.9$ \\
\hline Sundasciurus hippiurus & 1 & - & 1.0 & 0.5 & 0.2 \\
\hline Helarctos malayanus & 3 & - & 1.0 & 0.7 & 36.6 \\
\hline Sus barbatus & 18 & $58.0 \pm 19.5^{*}$ & $3.1 \pm 1.2$ & $17.3 \pm 9.0$ & $1059 \pm 551$ \\
\hline Tragulus spp. & 10 & - & 1.0 & 1.8 & 9.5 \\
\hline Muntiacus spp. & 22 & $46.7 \pm 9.8^{* * *}$ & $1.2 \pm 0.2$ & $2.8 \pm 1.4$ & $41.7 \pm 20.7$ \\
\hline All hornbills & 74 & $31.2 \pm 4.8^{* * *}$ & - & $15.1 \pm 2.8$ & $23.4 \pm 3.2$ \\
\hline Anorrhinus galeritus & - & - & 7 & 5.5 & 6.5 \\
\hline Anthracoceros malayanus & 36 & $50.0 \pm 11.1^{*}$ & $1.6 \pm 0.2$ & $3.4 \pm 1.4$ & $3.6 \pm 1.4$ \\
\hline A. albirostris & 1 & - & 1.0 & 0.1 & 0.04 \\
\hline Buceros rhinoceros & 41 & $33.3 \pm 8.8^{* * *}$ & $1.7 \pm 0.2$ & $3.7 \pm 1.2$ & $9.2 \pm 3.4$ \\
\hline B. vigil & 10 & - & 1.6 & 0.7 & 1.9 \\
\hline Aceros comatus & 1 & - & 4 & 0.3 & 0.4 \\
\hline A. corrugatus & 3 & - & 1 & 0.1 & 0.1 \\
\hline A. undulatus & 1 & - & 1.7 & 0.1 & 0.3 \\
\hline
\end{tabular}

${ }^{1}$ Significance levels are $\mathrm{P}<0.10^{*}, \mathrm{P}<0.05^{* *}, \mathrm{P}<0.001^{* * *}$.

density had tripled between this study and that of Bodmer et al. (1991a), while mouse deer density had remained unchanged (Table 2). No sambar deer Cervis unicolor were seen but at least one was taken by hunters (K.R.M., pers. obs.) from forest nearby during the study period.

Sun bears Helarctos malayanus were at a low density in the study area (Table 1). Only three sightings were recorded along the transects, but other signs (claw marks on trees and dung), indicated they were present in the area throughout the year. During the non-fig fruiting season, however, bears were heard frequently, more dung was found, and the actual density, based on three distinct individuals sighted in May (1.05 individuals $\left.\mathrm{km}^{-2}\right)$, is higher than the overall census estimate $(0.69$ individuals $\mathrm{km}^{-2}$ ). It is not certain whether these three bears were the resident population and the timing of the surveys did not provide complete data for this partly nocturnal species, or whether one or two individuals had immigrated into the area to exploit the large fruit crops.

The density of two large squirrel species, Prevost's squirrel Callosciurus prevostii and giant squirrel Ratufa affinis, appeared to be high (Table 1). A solitary horsetailed squirrel Sundasciurus hippiurus was seen once in the final month of the study. Sightings of giant $(d=0.33$, $\mathrm{P}>0.05)$ and Prevost's squirrels $(\mathrm{d}=0.35, \mathrm{P}>0.05) \mathrm{did}$ not alter over the study months.

Four hornbill species had resident populations at Barito Ulu (black Anthracoceros malayanus, rhinoceros
Buceros rhinoceros, bushy-crested Anorrhinus galeritus and helmeted $B$. vigil). Of these, bushy-crested and rhinoceros hornbills were the most abundant (Table 1). Combining all hornbill sightings, there was a clear relationship with fruit availability (Fig. 2). More birds were seen during the peak non-fig fruiting season $(\mathrm{r}=0.80, \mathrm{P}=0.005)$. Group size was also larger at this time, with sightings of groups of up to seven birds. Outside the fruiting season hornbills were only seen singly or in pairs. The changes in numbers were due both to fluctuations in the numbers of the resident species and also the appearance of two nomadic species, wrinkled Aceros corrugatus and wreathed hornbills $A$. undulatus, which only visited the study area when fruit was most abundant. Oriental pied Anthracoceros albirostris and white-crowned hornbills Aceros comatus were seen in the study area during the fruiting period, but also recorded during periods of lower fruit availability. In July and August black hornbills were breeding and three nests were found; they were not recorded in the census during this time. Rhinoceros hornbills were also conspicuously absent during these months and so may have been breeding.

We did not survey strictly nocturnal mammals, but the presence of several species was confirmed (Appendix 1). Flying foxes Pteropus vampyrus were only seen in the area in the last month of study, when the forest fires were well established. Sightings of other species were too opportunistic for the observation of any trends. 

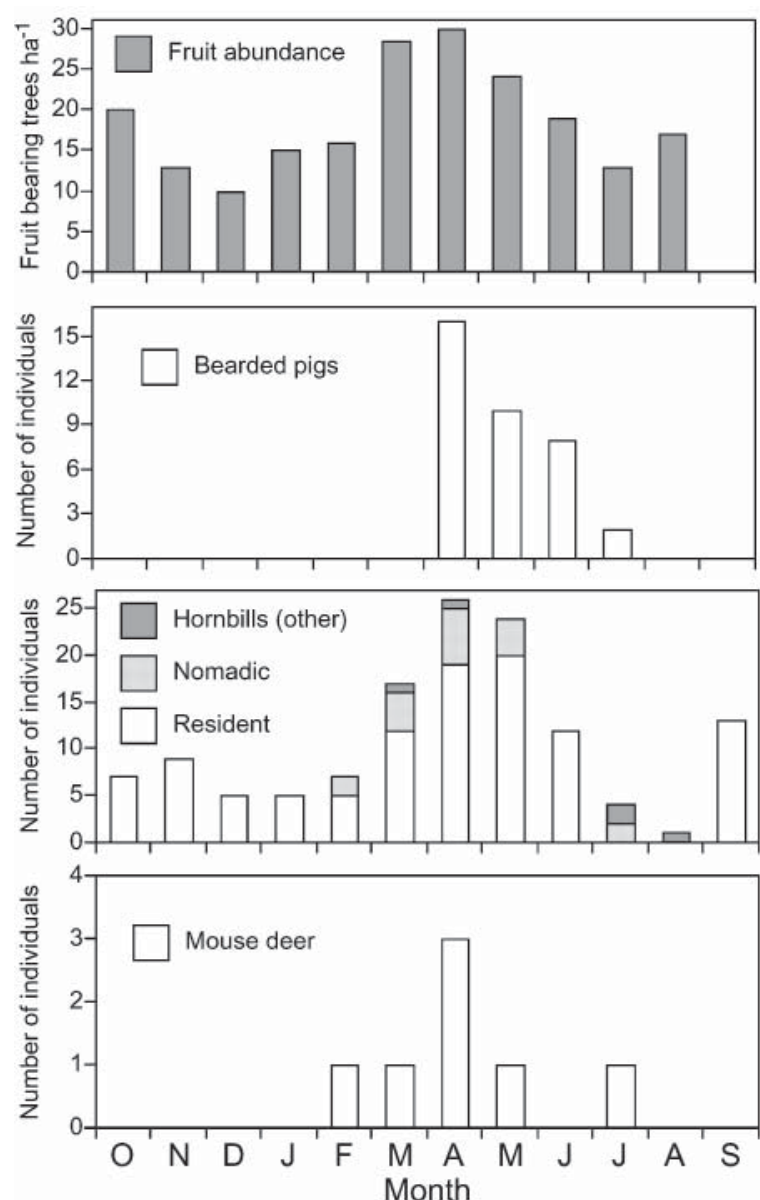

Fig. 2 Changes in frequency of non-fig fruit abundance (number of fruit sources $>10 \mathrm{~cm}$ DBH per hectare), and bearded pig, hornbill and mouse deer sightings at Barito Ulu, Central Kalimantan, throughout the year.

Table 2 Densities of primates and ungulates (individuals per $\mathrm{km}^{2}$ ) from Bodmer et al. (1991a) and the present study at Barito Ulu. Estimates from Bodmer et al. (1991a) were calculated using Fourier series expansion of line transects.

\begin{tabular}{lcl}
\hline Species & $\begin{array}{l}\text { 2 months (1989; } \\
\text { Bodmer } \text { et al., 1991a) }\end{array}$ & $\begin{array}{l}\text { 11 months (1996-1997; } \\
\text { present study) }\end{array}$ \\
\hline Hylobates spp. & 7.2 & 8.2 \\
Presbytis rubicunda & 10.4 & 8.4 \\
Macaca fascicularis & 1.4 & 1.5 \\
Pongo pygmaeus & $<0.1$ & 0.0 \\
Muntiacus spp. & 0.9 & 2.8 \\
Tragulus spp. & 2.0 & 1.8 \\
Sus barbatus & 1.2 & 17.3 (migration) \\
\hline
\end{tabular}

A full list of all mammal species seen at Barito Ulu in this study and in previous years is given in the Appendix. A list of birds is given by Wilkinson et al. (1991).

\section{Discussion}

The forests of Barito Ulu supported a lower biomass of large mammals and hornbills than most other areas in Borneo that have been surveyed (Table 3). Kutai National Park had more than five times the hornbill and primate biomass of Barito Ulu (Rodman, 1978; Leighton, 1982). Even langurs and gibbons, the species that consistently had the highest biomass at Barito Ulu, were still less abundant there than in most other sites, although gibbons had the lowest biomass at Kayan Mentarang and Sungai Wain (Nijman, 2001). Bearded pigs had the highest overall density at Barito Ulu during this study, but the resident population is probably low as there was no sign of pigs prior to April. Pigs periodically migrate through Borneo (Pfeffer \& Caldecott, 1986), and the migration passed through our camp over 4 months during the annual peak of fruit abundance.

There was a major difference in faunal composition between Barito Ulu and most other sites surveyed in Borneo and, although numbers of some species were particularly low at Barito Ulu, a few species were at relatively high density. Barito Ulu was depauperate in the largest primate species, orang-utan and pig-tailed macaque. Lone, probably nomadic, males of both species have been seen in previous years (Dutson, 1989; Mather 1992) but no breeding groups appear to occur. The more nomadic hornbill species, which tend to congregate in large flocks, were also rarely seen. The large difference in hornbill biomass between Kutai and Barito Ulu was due to the near absence of the nomadic species at the latter, whereas resident hornbill species at Barito Ulu had equivalent or denser populations than at any other site.

There are five possible explanations for the low densities and particular faunal composition at Barito Ulu compared to other sites in Borneo: hunting pressure, isolation, fruit and staple food supplies, poor soils, and specific habitat preferences. Wildlife has been harvested in Borneo for at least 35,000 years, and human communities in the interior appear to have had the most long-term impact on wildlife populations (Bennett et al., 2000). These communities are believed to have caused the local extinction of several species and this can be seen, for example, in the mutually exclusive distributions of humans and orang-utans (Rijksen \& Meijaard, 1999). Bennett et al. (2000) surveyed various communities in Sarawak and found that while $<9 \%$ of communities in coastal areas ate wild meat daily, this increased to $37 \%$ in more remote traditional rural areas where communities use old hunting practices and are less affected by a cash economy; logging camps had the highest rate at $49 \%$. Nomadic Orang Ut lived in the upper Barito area during Dutch colonial times (Schwaner, 1853) and Dayak and Muslim communities were present in the Barito region 
Table 3 Biomass $\left(\mathrm{kg} \mathrm{km}^{-2}\right)$, where available, of large diurnal mammals, other than orang-utans, and hornbills in three areas of interior forest and four areas of coastal forest in Borneo.

\begin{tabular}{|c|c|c|c|c|c|c|c|}
\hline \multirow[b]{2}{*}{ Species } & \multicolumn{3}{|c|}{ Interior forest } & \multicolumn{4}{|c|}{ Coastal forest } \\
\hline & Barito Ulu ${ }^{1}$ & $\begin{array}{l}\text { Lanjak } \\
\text { Entimau }^{2}\end{array}$ & $\begin{array}{l}\text { Kayan } \\
\text { Mentarang }\end{array}$ & Kutai $^{4}$ & $\begin{array}{l}\text { Sungai } \\
\text { Wain }^{5}\end{array}$ & Sabah $^{6}$ & Sarawak $^{7}$ \\
\hline No. months studied & 12 & 8 & 3 & 16 & 3 & 4 & 23 \\
\hline Altitude (m) & $100-350$ & $170-625$ & $350-750$ & $30-300$ & $50-127$ & $<500$ & \\
\hline Hornbills & 23.4 & & & 103.9 & & & \\
\hline Buceros rhinoceros & 9.2 & 4.3 & & 2.8 & & 5.3 & \\
\hline B. vigil & 1.9 & present & & 0.9 & & 46.7 & \\
\hline Anthracoceros malayanus & 3.4 & 3.5 & & 2.8 & & 3.3 & \\
\hline A. albirostris & 0.6 & & & & & & \\
\hline Anorrhinus galeritus & 5.5 & 3.3 & & 7.3 & & & \\
\hline Aceros comatus & 0.4 & & & 5.5 & & & \\
\hline A. corrugatus & 0.1 & 1.0 & & 20.7 & & & \\
\hline A. comatus & 0.3 & & & 71.2 & & 11.2 & \\
\hline Primates & 106.9 & 306.1 & & 510.5 & & 314.0 & \\
\hline Presbytis spp. ${ }^{8}$ & $52.5(\operatorname{Pr})$ & 183.1 (Pr, Pf) & & $128.5(\mathrm{~Pa})$ & & 111.01 & \\
\hline Macaca fascicularis & 7.7 & 6.2 & & 29.0 & & 63.0 & \\
\hline M. nemestrina & Rare & 7.7 & & 35.8 & & 50.0 & \\
\hline Hylobates spp. & 46.7 & 91.0 & 33.7 & 83.2 & 39.5 & 52.0 & \\
\hline Pongo pygmaeus & Rare & 18.1 & & 234.0 & & 38.0 & \\
\hline \multicolumn{8}{|l|}{ Other } \\
\hline Ratufa spp. & 6.1 & & & & & & 11.7 \\
\hline Callosciurus spp. & 5.5 & & & & & & 4.1 \\
\hline Sundasciurus spp. & 0.2 & & & & & & 2.4 \\
\hline Helartos malayanus & 36.6 & & & & & 53.0 & \\
\hline Tragulus spp. & $76.0^{9}$ & & & & & 295.0 & \\
\hline
\end{tabular}

${ }^{1}$ This study

${ }^{2}$ Blouch, 1997 (line transect)

${ }^{3}$ Meredith, 1995 (line transect, Fourier series analysis)

${ }^{4}$ Rodman, 1978 (primates, actual densities known); Leighton, 1982 (hornbills, line transect)

${ }^{5}$ Nijman, 2001 (actual densities known)

${ }^{6}$ Payne \& Davis, 1982 (line transect), Heydon \& Bulloh, 1997 (Tragulus, line transect, DISTANCE)

${ }^{7}$ Bennett \& Dahaban, 1995 (line transect, Fourier series analysis)

${ }^{8} \mathrm{~Pa}$, Presbytis aygula; $\mathrm{Pr}$, P. rubicunda; Pf, P. frontata

${ }^{9}$ Actual value (9.5) is multiplied by 8 for a more accurate comparison with the night-time surveys of Heydon \& Bulloh (1997) (see text for details)

during this study. Continual hunting in the upper Barito area may keep faunal populations low or they may be recovering from previous hunting pressure. Muntjac density during this study was three times higher than during a census in 1989 (Bodmer et al., 1991a) and this may indicate a rise in the study site's population due to a reduction in hunting in the immediate study area because of the presence of researchers. However, we have no explanation for why densities of other species were unchanged.

Barito Ulu's isolation may also partly explain the low densities of animals surveyed in this study. To the north of the study site are large tracts of heath forest that support relatively few species (K.R. McConkey, unpubl. data), and to the south and east of the study site nonvolant animals may be prevented from entering the area by the fast flowing Busang and Murung Rivers. To reach the area the animals would either have to swim, or continue up-river to a suitable crossing place and then travel back down river. Thus, regular visits by nonresident frugivorous animals, such as orang-utans and pig-tailed macaques, are restricted. However, hornbills and pigs would not be prevented by these obstacles; both were seen in the heath forest to the north and both can cross rivers. This observation is also supported by the fact that orang-utans do not occur in south-east Borneo east of the Barito (Rijksen \& Meijaard, 1999); if orangutans are locally extinct in this region then there is a clear migration bottleneck between the upper Mahakam and upper Barito Rivers.

Bodmer et al. (1991a) suggested that the low biomass of primates, particularly the rarity of orang-utans, and ungulates in Barito Ulu was due to poor fruit supplies. All the large diurnal animals discussed here consume 
fruit, and the scarcity of single, large fruit sources may be limiting for certain species (Caldecott, 1983; Leighton, 1993; Lawrence \& Leighton, 1996). During the study period the monthly density of single large fruit sources (trees with $\mathrm{DBH}>25 \mathrm{~cm}$ ) varied between 0.4 and 6.1 trees ha ${ }^{-1}$ (K.R. McConkey, unpubl. data), which is less than a third that reported by Leighton (1993) in Kutai (20 trees ha-1 during a non-mast peak). This lack of large fruit trees could explain Barito Ulu's low density of orang-utans and of species that tend to associate in large flocks or groups, such as long-tailed and pig-tailed macaques and Aceros hornbills (Caldecott, 1983; Robertson, 1986; Leighton, 1993; Lawrence \& Leighton 1996; Yeager, 1996). In comparison, Barito Ulu has sizeable gibbon populations, reflecting this species' behaviour of moving around and defending a home range of mainly small fruit trees (Chivers, 1984). Rhinoceros, helmeted and black hornbills had higher densities at Barito Ulu than at other sites. Because these species tend to forage singly or in pairs, they may also be able to cope with smaller fruit supplies, and reduced competition, due to the low density of the flocking hornbill species, may also be beneficial.

Barito Ulu may also lack specific staple food to support a resident population of some animal species. For example, the palm Borassodendron borneensis is considered an important staple for orang-utans (Rijksen \& Meijaard, 1999) yet appears to be absent from the study area (Awmack, 1992). On the other hand, the six plant genera identified by Blouch (1997) to be the best indicators of orang-utan density in Lanjak Entimau in Sarawak (Artocarpus, Baccaurea, Durio, Garcinia, Lithocarpus and Nephelium) were found at Barito Ulu in densities in the upper range of that at Blouch's study site (McConkey, 1999), although it is possible they are less productive at Barito. Similarly, mouse deer densities have been related to the amount of reproductive figs and small fruit in the forest (Heydon \& Bulloh, 1997). At Barito Ulu the density of mouse deer was lower than at Segama in Sabah, with a corresponding, but unproportional, decrease in reproductive fig density (McConkey, 1999).

Barito Ulu has poor, acidic soils compared to other South-east Asian lowland forests (Mirmanto, 1996). Payne (1995) found that large mammals in Malaysia were most abundant on mineral-rich soils and suggested that mineral availability could limit mammal density. Hence, Barito Ulu's poor soils may explain its lower availability of large fruit trees, as well as the low mammal density.

The absence or rarity of some species may be linked to the lack of a specific habitat. Oriental-pied hornbills prefer secondary growth and riverine forest (Leighton, 1982; Kemp, 1995). Although these habitats were not rare at Barito Ulu, they were not well sampled in this study, and it is possible that higher Oriental pied hornbill densities exist in these specific habitats. Similarly, longtailed macaques also prefer riverine forest, occasionally travelling inland to exploit certain resources (Fittinghoff \& Lindburg, 1980); their low density along the non-riverine transects may reflect this habitat preference. Woodd et al. (1993) calculated a density of $c .15$ macaques $\mathrm{km}^{-2}$ along the river edge at Barito Ulu, which is ten times higher than the estimate from this study. Proboscis monkeys are absent from the study area, although they have once been sighted nearby (Chivers, 1996); the riverine forest along the Busang is probably unsuitable for them as it is rugged and appears to be of low quality compared to areas where proboscis monkeys are normally seen.

There are several potential problems with the information reported here. Firstly, The survey was carried out in 1996-97. With the exception of muntjacs, there was little change in abundance of pigs, mouse deer and primates between 1989 (Bodmer, 1991a) and this study; hence, at least during this period, densities appeared to be stable. Moreover, since 1997 there have been few changes in the immediate Barito Ulu area that are likely to have affected wildlife populations (R. Ridgeway, pers. comm.). The most significant potential impact may be from the logging camp $10 \mathrm{~km}$ up-river. Logging began in 1997 and ceased in 2002 (R. Ridgeway, pers. comm.); in Sarawak hunting pressure has been shown to be particularly high around logging camps (Bennett et al., 2000). On the other hand, illegal logging is reportedly minimal in the region (R. Ridgeway, pers. comm.). Boat transport on the Busang has decreased since the study period, down from at least one speedboat per day to just 1-2 a week in 2004 (R. Ridgeway, pers. comm.). However, rafts for the extraction of gold from river sediment have begun to appear about $5 \mathrm{~km}$ above the study site, and this has caused an increase in slow boat transport and probably hunting (R. Ridgeway, pers. comm.). Secondly, most of the surveys from other regions of Borneo that we have used for comparison are even older than our survey and there is a lack of more recent published data. Survey methods also differed, but the variety we used in our study encompassed the range found in the other studies (distance sampling, line transect surveys, and known densities). Thirdly, some animal species, such as mouse deer and sambar deer, are primarily active around dawn and dusk and the morning census is not likely to accurately reflect their true density. Heydon \& Bulloh (1997) found that mouse deer sightings in Sabah were seven to eight times higher at night than during the day. Even if we multiply the mouse deer density in Barito Ulu by eight times, it is still $25 \%$ of that reported by Heydon \& Bulloh (1997). Similarly, sambar deer may be present at Barito Ulu Research Area, but daytime surveys are not suitable for recording them. A sambar deer was hunted by people from the local village of Muara Joloi during the 
study period (K.R.M., pers. obs), although it is not known where the deer came from.

Kalimantan's forests are seriously threatened by activities such as legal and illegal logging, agriculture, plantations, road construction and forest fires (Rijksen \& Meijaard, 1999). Much of the prime habitat for many animal species has already been destroyed or modified, and the richer, accessible, coastal areas are most threatened. The more remote interior forests are likely to become increasingly important in sustaining many animal species. If the density of animals at Barito Ulu is representative of much of Kalimantan's unsurveyed areas then a large area would be needed to conserve viable numbers of most species. It is crucial that further surveys are carried out, in a diversity of vegetation types, to ensure that we have a full understanding of the carrying capacity of different areas.

\section{Acknowledgements}

We thank the Ministry of Forestry and LIPI in Indonesia for their support and permission to conduct research at the Barito Ulu Site. Rupert Ridgeway of Project Barito Ulu provided logistical support and Bapaks Nurdin and the late Suriantata assisted in data collection. Thanks to M.C.M. Kierulff, W.R. Spironello and M. Galetti for discussions on the work and S. Bricknell, R. Ridgeway, R. Commitante and S. Cheyne for providing information. Financial assistance was provided by the New Zealand Federation of University Women, Cambridge Commonwealth Trust, Isaac Newton Trust, Leakey Foundation, Selwyn College, Cambridge University, Cambridge University Board of Graduate Studies, Primate Conservation Inc. and Sophie Danforth Conservation Biology Fund of the Roger Williams Park Zoo and Rhode Island Zoological Society.

\section{References}

Awmack, C. (1992) A Checklist for the Palm Flora of Barito Ulu, Kalteng. Unpublished Report, Project Barito Ulu, Indonesia.

Bennett, E.L., Nyaoi, A.J. \& Sompud, J. (2000) Saving Borneo's bacon: the sustainability of hunting in Sarawak and Sabah. In Hunting for Sustainability in Tropical Forests (eds J.G. Robinson \& E.L. Bennett), pp. 305-324. Columbia University Press, New York, USA.

Blouch, R.A. (1997) Distribution and abundance of orang-utans (Pongo pygmaeus) and other primates in the Lanjak Entimau Wildlife Sanctuary, Sarawak, Malaysia. Tropical Biodiversity, 4, 259-274

Bodmer, R.E., Sidik, I. \& Iskander, S. (1991a) Mammalian Biomass Shows that Uneven Densities of Orang-utans are Caused by Variation in Fruit Availability. Unpublished Report. University of Cambridge, Cambridge, UK.

Bodmer, R.E., Mather, R.J. \& Chivers, D.J. (1991b) Rain forests of central Borneo-threatened by modern development. Oryx, $25,21-26$.
Caldecott, J.O. (1983) An ecological study of the pig-tailed macaque in Peninsular Malaysia. PhD thesis, University of Cambridge, UK.

Chivers, D.J. (1984) Feeding and ranging in gibbons: a summary. In The Lesser Apes: Evolutionary and Behavioural Biology (eds H. Presuchoft, D.J. Chivers, W.Y. Brockelman \& N. Creel), pp. 74-80. Edinburgh University Press, Edinburgh, UK.

Chivers, D.J. (1992) Socio-ecology and conservation of gibbons in South-east Asia, with special reference to Borneo. In Forest Biology and Conservation in Borneo (eds G. Ismail, M.

Mohamed \& S. Omar), pp. 230-244. Center for Borneo

Studies Publication No. 2, Yayasan Sabah, Kota Kinabalu, Malaysia.

Chivers, D.J. (1996) Project Barito Ulu Quinquennial Report 92-96. Unpublished Report. University of Cambridge, Cambridge, UK.

Dutson, G. (1989) The Avifauna of Barito Ulu. Unpublished Report. University of Cambridge, Cambridge, UK.

Eisenberg, J.K., Wolfgang, P.J.D., Fleming, P.J.D., Green, T.H., Struhsaker, K., Thorington, T., Altman, J.R.W., Brockett, N.H., Goy, B.G. \& Marriott, R.W. (1981) Techniques for the Study of Primate Population Ecology. National Academy Press, Washington, DC, USA.

Felton, A.M., Engström, L.M., Felton, A. \& Knott, C.D. (2003) Orang-utan population density, forest structure and fruit availability in hand-logged and unlogged peat swamp forests in West Kalimantan, Indonesia. Biological Conservation, 114, 91-101.

Fitinghoff, J. \& Lindburg, D.G. (1980) Riverine refuging in East Bornean Macaca fascicularis. In The Macaques: Studies in Ecology, Behaviour and Evolution (ed. D.G. Lindburg), pp. 182-214. Van Nostrand Reinhold Company, New York, USA.

Galdikas, B.M.F. (1988) Orang-utan diet, range and activity at Tanjung Puting, Central Borneo. International Journal of Primatology, 9, 1-35.

Hall, J.C. (1995) Things Change to Remain the Same: A Return to Muara Joloi. Unpublished Report. University of Cambridge, Cambridge, UK.

Hearn, A.J. \& Bricknell, S. (2003) Bay cat sightings in Kalimantan. Cat News, 39, 3.

Heydon, M.J. \& Bulloh, P. (1997) Mouse deer densities in a tropical rainforest: the impact of selective logging. Journal of Applied Ecology, 34, 484-496.

IUCN (2003) 2003 IUCN Red List of Threatened Species. IUCN, Gland, Switzerland and Cambridge, UK [http:/ / www.redlist.org, accessed 12 July 2004].

Kemp, A. (1995) The Hornbills. Oxford University Press, Oxford, UK.

Laake, J.L., Buckland, S.T., Anderson, D.R. \& Burnham, K.P. (1994) Distance User's Guide. Version 2.1. Colorado Co-operative Fish and Wildlife Research Unit. Colorado State University, Fort Collins, USA.

Lawrence, D.C. \& Leighton, M. (1996) Ecological determinants of feeding bout length in long-tailed macaques (Macaca fascicularis). Tropical Biodiversity, 3, 227-242.

Leighton, M. (1982) Fruit resources and patterns of feeding, spacing and grouping among sympatric Bornean hornbills (Bucerotidae). $\mathrm{PhD}$ thesis, Stanford University, USA.

Leighton, M. (1993). Modeling dietary selectivity by Bornean orang-utans: evidence for integration of multiple criteria in fruit selection. International Journal of Primatology, 14, 257-313. 
Leighton, M. \& Leighton, D.R. (1983) Vertebrate responses to fruiting seasonality within a Bornean rain forest. In Tropical Rainforest: Ecology and Management (eds S.L. Sutton, T.C. Whitmore \& A.C. Chadwick), pp. 181-196. Blackwell Scientific Publications, Oxford, UK.

Mackinnon, K., Hatta, G., Halim, H. \& Mangalik, A. (1996) The Ecology of Kalimantan. Periplus Editions, Singapore.

Mather, R. (1992) Distribution and abundance of primates in Northern Kalimantan Tengah: comparisons with other parts of Borneo and Peninsular Malaysia. In Forest Biology and Conservation in Borneo (eds G. Ismail, M. Mohamed \& S. Omar), pp. 175-189. Center for Borneo Studies Publication No. 2, Yayasan Sabah, Kota Kinabalu, Malaysia.

McConkey, K.R. (1999) Gibbons as seed dispersers in the rain-forests of central Borneo. $\mathrm{PhD}$ thesis, University of Cambridge, UK.

McConkey, K.R., Ario, A., Aldy, F. \& Chivers, D.J. (2003) The influence of forest seasonality on gibbon food choice in the rainforests of central Borneo. International Journal of Primatology, 24, 19-32.

Nijman, V. (2001) Forest and Primates: Conservation and Ecology of the Endemic Primates of Java and Borneo. TropenbosKalimantan Series 5, Wageningen, The Netherlands.

Meredith, M.E. (1995) A faunal survey of Batang Ai National Park, Sarawak, Malaysia. Sarawak Museum Journal, 48, 133-155.

Mirmanto, E. (1996) A lowland rain forest fertilization experiment in Central Kalimantan, Indonesia. MSc thesis, University of Stirling, UK.

Mueller-Dombois, D. \& Ellenberg, H. (1974) Aims and Methods of Vegetation Ecology. John Wiley and Sons, Toronto, Canada.

Payne, J.C. \& Davies, A.G. (1982) A Faunal Survey of Sabah. IUCN/WWF, Project No. 1692, Unpublished report. WWF Malaysia, Kuala Lumpur, Malaysia.

Payne, J., Francis, C. \& Phillips, C. (1985) A Field Guide to the Mammals of Borneo. Sabah Society and WWF Malaysia, Kota Kinabalu, Malaysia.

Payne, J. (1995) Links between vertebrates and the conservation of southeast Asian rainforests. In Ecology, Conservation, and Management of South-east Asian Rainforests (eds R.B. Primack \& T.E. Lovejoy), pp. 54-65. Yale University Press, New Haven, USA and London, UK.

Pfeffer, P. \& Caldecott, J. (1986) The bearded pig in East Kalimantan and Sarawak. British Royal Asiatic Society, 59, 81-100.

Proctor, J., Brearley, F.Q., Dunlop, H., Proctor, K., Supramono \& Taylor, D. (2001) Local wind damage in Barito Ulu, Central Kalimantan: a rare but essential event in a lowland dipterocarp forest? Journal of Tropical Ecology, 17, 473-475.

Rijksen, H.D. \& Meijaard, E. (1999) Our Vanishing Relative: The Status of Wild Orang-utans at the Close of the Twentieth Century. Kluwer Academic Publishers, Dordrecht, The Netherlands.
Robertson, J.M.Y. (1986) On the evolution of pig-tailed macaque societies. PhD thesis, University of Cambridge, UK.

Robinson, M. (1989) Chiroptera Survey. Unpublished Report. University of Cambridge, Cambridge, UK.

Rodman, P.S. (1978) Diets, densities and distributions of Bornean primates. In The Ecology of Arboreal Folivores (ed. G.G. Montgomery), pp. 465-480. Smithsonian Institution Press, Washington, DC, USA.

Russon, A.E., Erman, A. \& Dennis, R. (2001) The population and distribution of orang-utans (Pongo pygmaeus pygmaeus) in and around the Danau Sentarum Wildlife Reserve, West Kalimantan, Indonesia. Biological Conservation, 97, 21-28.

Schwaner, C.A.L.M. (1853) Borneo: Description of the Barito River Basin and Travel Along Several of the Important Rivers of the South-easterly Section of the Island: Undertaken by Order of the Netherlands Indies Government in the Years 1843-1847. P. N. van Kampen, Amsterdam, The Netherlands.

Statsoft (1994) STATISTICA for the MacIntosh, version 4.1. Statsoft, Tulsa, USA.

Wilkinson, R., Dutson, G., Sheldon, B., Darjono \& Rusila-Noor, Y. (1991) The avifauna of the Barito Ulu region, Central Kalimantan. Kukila, 5, 99-116.

Woodd, A., Sharpe, R., Rees, L. \& Johnstone, K. (1993) Project Macaque. Unpublished Report. University of Cambridge, Cambridge, UK.

Yeager, C. P. (1996) Feeding Ecology of the long-tailed macaque (Macaca fascicularis) in Kalimantan Tengah, Indonesia. International Journal of Primatology, 17, 51-62.

\section{Appendix}

The appendix for this article is available online at http:/ /journals.cambridge.org

\section{Biographical sketches}

Kim McConkey is an ecologist interested in plant-animal interactions, particularly the role of large mammals in seed dispersal, in Asia and the tropical Pacific. She has conducted research in Indonesia, Tonga and New Zealand, and has recently moved to India.

David Chivers is Vice-Chairman of Fauna \& Flora International. $\mathrm{He}$ has extensive research experience in the socioecology and conservation of rainforest animals, particularly primates, in South-east and South Asia and Brazil. 